\title{
Evaluation of malnutrition status and clinical indications in children with celiac disease: a cross-sectional study
}

\author{
Zahra Setavand ${ }^{1}$, Maryam Ekramzadeh ${ }^{2^{*}}$ and Naser Honar ${ }^{3}$
}

\begin{abstract}
Background: Celiac Disease (CD) is an autoimmune systemic disorder triggered by gluten in genetically susceptible individuals, which can lead to chronic malabsorption. Considering the changes in the manifestations of $C D$, this study aimed to determine anthropometric indices and clinical indications in children with CD.

Methods: This cross-sectional study aimed to evaluate the children with CD who had referred to Imam Reza Celiac Clinic between 2016 and 2019. Totally, 361 children were eligible and their anti-tissue transglutaminase (TGA-IgA) level, weight, height, and Body Mass Index (BMI) were extracted from their records. The anthropometric indices were presented based on the criteria of the Center for Disease Control and Prevention (CDC) and World Health Organization (WHO). The prevalent symptoms were assessed, as well.

Results: Based on the CDC's criteria, 18.3, 28.8, and 25.8\% of the children had short stature, low body weight, and low BMI, respectively. These measures were obtained as 10, 22.4, and 13.9\% according to the WHO's categorization respectively. Furthermore, the most common symptoms among the children were abdominal pain (56.5\%), skeletal pain (28\%), constipation (27.4\%), and anemia (23.8\%).

Conclusion: To sum up, the results clearly indicated that growth failure and low height, weight, and BMI were prevalent among the children with CD. Moreover, in addition to gastrointestinal symptoms, a considerable number of patients had skeletal pain and anemia.
\end{abstract}

Keywords: Celiac disease, Children, Stature, Body weight, BMI, Gluten, Growth

\section{Background}

Celiac Disease (CD) is known as a chronic autoimmune enteropathy triggered by storage protein of wheat, barley, and rye called gluten, which has been reported to have a wide range of clinical features $[1,2] . C D$ is a multifactorial disorder affected by the interaction between gluten ingestion and immune response as well as environmental and genetic factors [3]. Worldwide assessments have demonstrated that $\mathrm{CD}$ affected almost $1 \%$ of the

\footnotetext{
* Correspondence: mekramzade@gmail.com

${ }^{2}$ Nutrition Research Center, Department of Clinical Nutrition, School of Nutrition and Food Sciences, Shiraz University of Medical Sciences, Shiraz, Iran

Full list of author information is available at the end of the article
}

European population [4]. Based on serological evaluations in Iran, the prevalence of CD was reported 1 out of 167 children [5]. However, the prevalence of $\mathrm{CD}$ has been found to be higher in a variety of diseases, such as Irritable Bowel Syndrome (IBS), diabetes, and neurological disorders (11, 12, and 3.7\%, respectively) [6]. Formerly, CD was only considered in patients with obvious malabsorption and Gastrointestinal (GI) manifestations, including abdominal distension, abdominal pain, chronic diarrhea, constipation, nausea, and vomiting [7-9]. Nowadays, however, there is no sign of classical symptoms in many patients and extraintestinal symptoms, such as growth failure, dental enamel defect, and iron-deficiency anemia, have become dominant.

(c) The Author(s). 2021 Open Access This article is licensed under a Creative Commons Attribution 4.0 International License, which permits use, sharing, adaptation, distribution and reproduction in any medium or format, as long as you give appropriate credit to the original author(s) and the source, provide a link to the Creative Commons licence, and indicate if changes were made. The images or other third party material in this article are included in the article's Creative Commons licence, unless indicated otherwise in a credit line to the material. If material is not included in the article's Creative Commons licence and your intended use is not permitted by statutory regulation or exceeds the permitted use, you will need to obtain permission directly from the copyright holder. To view a copy of this licence, visit http://creativecommons.org/licenses/by/4.0/ The Creative Commons Public Domain Dedication waiver (http://creativecommons.org/publicdomain/zero/1.0/) applies to the data made available in this article, unless otherwise stated in a credit line to the data. 
In fact, the clinical symptoms of $\mathrm{CD}$ go beyond GI presentations [9]. According to the Oslo classification of $\mathrm{CD}$, different types of classic, non-classic, subclinical, potential, and refractory has been identified $[10,11]$. The classic CD is characterized by signs and symptoms of malabsorption and the non-classic one presents with extra-intestinal symptoms. The subclinical CD is below the threshold of clinical detection. In potential $\mathrm{CD}$, the patients at risk of developing the disease are recognized [12]. Mucosal damage of the proximal part of the intestine and fat malabsorption cause nutrients, vitamins (D, K, and B9), and minerals (iron and zinc) deficiency, which can in turn increase the risk of hypocalcemia, rickets, osteoporosis, coagulation disorders, anemia, and malnutrition [13-16]. In addition to nutrients malabsorption, reduced food intake is associated with poor growth in pediatric patients with CD [17]. Furthermore, decrease in Insulin Growth Factor-1 (IGF-1) and Growth Hormone (GH) levels may be correlated to their impaired nutritional status. These pathways lead to various extraintestinal manifestations of $\mathrm{CD}$, such as short stature, growth retardation, and delayed puberty, which should be taken into account when dealing with children suffering from $C D[15,18]$. Considering the data regarding the increasing trend in the incidence of $\mathrm{CD}$ [19], evaluation, diagnosis, and management of its clinical symptoms are essential.

Since CD has a heterogeneous spectrum of symptoms, proper growth of children is of paramount importance. Considering the lack of data regarding malnutrition, growth pattern, and dominant clinical nutrition related symptoms in the Iranian pediatrics with $\mathrm{CD}$, the present study aims to investigate the anthropometric features and clinical manifestations of children with $\mathrm{CD}$. The information extracted from this study will enable us to ameliorate CD-related complications in the future studies.

\section{Methods}

\section{Study design}

The present cross-sectional study was a part of a retrospective cohort assay conducted on patients with $\mathrm{CD}$. The participants were selected from the patients with medical records referred to Imam Reza specialized nutrition and diet therapy clinic for CD affiliated to Shiraz University of Medical Sciences, Shiraz, Iran from September 2016 to September 2019. Mucosal atrophy at the biopsies was described by an expert pathologist. Then CD diagnosis confirmed by a gastroenterologist based on biopsy results and anti-tissue transglutaminase (TGA-IgA). The inclusion criteria were age between 2 and 18 years, positive diagnosis of $\mathrm{CD}$ by a specialist, and completed relevant forms about the personal information and clinical signs of $\mathrm{CD}$. Patients with other chronic disorders [renal diseases, cirrhosis, malignancies, and organ failures] were excluded.
The study was approved by the Ethics Committee of Shiraz University of Medical Sciences (IR.SUMS.REC.1398.1153). Entirely, the medical records of 361 patients were reviewed and included in the analysis. The patients were assured about the confidentiality of their information.

\section{Participants' characteristics}

The researchers extracted the participants' demographic and anthropometric information from data records. Data including age, time of diagnosis, anti-tissue transglutaminase (TGA-IgA), related comorbidities [Type 1 Diabetes Mellitus (DMT1), Hashimoto thyroiditis etc], clinical symptoms, weight, height, and Body Mass Index (BMI) were collected after diagnosis and at their first visit to specialized nutrition and diet therapy clinic. Height was measured by a stadiometer to the nearest $0.1 \mathrm{~cm}$ without shoes. Weight was also measured by a calibrated scale (Omron, Korea) with an accuracy of $0.1 \mathrm{~kg}$ [20]. Anthropometric indices, including weight, height, and BMI (weight $(\mathrm{kg}) /$ height $\left(\mathrm{m}^{2}\right)$ ) [21], were presented based on the criteria of the Center for Disease Control and Prevention (CDC) and World Health Organization (WHO). Based on the CDC criteria for stature and weight for age, values less than the 5 th percentile, between the 5 th and the 95th percentiles, and higher than the 95th percentile were classified as unfavorable, normal, and high, respectively. In addition, BMI values $<$ the 5 th percentile, between the 5 th and the 85 th percentiles, and $\geq$ the 95th percentile were categorized as underweight, normal weight, and overweight and obese, respectively [22]. Considering the WHO's references, height and weight values $<-2 \mathrm{z}$-score, between -2 to +2 , and $\geq+2$ were categorized as low, sufficient, and high, respectively. In addition, $z$-scores $<-3,-3--2,-2-1,1-2$, and $\geq 2$ for BMI indicated severe thinness, thinness, normal status, overweight, and obesity, respectively [23].

\section{Clinical manifestations assessment}

A questionnaire was used to assess the prevalent symptoms among the children with $\mathrm{CD}$, including diarrhea, flatulence, abdominal pain, abdominal distention, constipation, skeletal pain (including both osteopenia related pain at legs and arthralgia induced by autoimmune diseas), hair loss, skin dryness, weight loss, diabetes, hypothyroidism, anemia, lactose intolerance, and nausea.

\section{Statistical analysis}

All analyses were performed using the SPSS software, version 21 (SPSS Inc., Chicago, IL, USA). The normality of the data was assessed using Kolmogorov-Smirnov test. Frequency and percentage were reported to describe the qualitative variables and mean and Standard Deviation (SD) were used for quantitative variables. Mann- 
Whitney and Kruskal-Wallis tests were used to assess the effect of disease duration on anthropometric indices. $P<0.05$ was considered statistically significant.

\section{Results}

\section{Participants}

The study results indicated that out of the 361 subjects, 63.7\% $(n=230)$ were female. The mean age of the patients was $9.55 \pm 3.72$ years, and there was no significant difference between the females $(9.35 \pm 0.32)$ and males $(9.89 \pm 3.73)$ with respect to age.

Sixty-two participants (17.2\%) had Type 1 Diabetes Mellitus (T1DM) and 29 ones (8\%) had hypothyroidism. Demographic and anthropometric data of the children with celiac disease are summarized in Table 1.

\section{Height for age values in the children with $C D$}

According to the resultspresented in Table 2, based on the CDC percentiles of height for age, 66, 290, and 5 patients have short, normal, and tall, respectively. However, considering the categorization of WHO z-scores, 36, 324 , and 1 patients had low, normal, and high values of height for age, respectively.

\section{Weight for age values in the children with CD}

Based on the results presented in Tables 3, 104, 252, and 5 patients were in the low, normal, and high percentiles of weight for age, respectively. In addition, the z-scores of weight for age were lower than -2 in 81 children, between -2 and +2 in 276 , and higher than +2 in four children.

Table 1 Demographic and anthropometric data of the children with celiac disease

\begin{tabular}{lll}
\hline Variable & Range & Celiac patients \\
\hline Age & $2-18$ & $9.55 \pm 3.72[9.16-9.93]^{\mathrm{a}}$ \\
Age at diagnosis & $1-17.33$ & $8.00(5.00)[7.84-8.55]$ \\
TGA-lgA $^{\mathrm{b}}(\mathrm{U} / \mathrm{ml})$ & $0.9-972$ & $59.80(114.75)[98.04-142.80]$ \\
Height $(\mathrm{cm})$ & $79-180$ & $130.12 \pm 20.51[128.00-132.25]$ \\
Weight $(\mathrm{kg})$ & $8.10-103.30$ & $25.10(17.85)[26.97-29.70]$ \\
BMl $\left(\mathrm{kg} / \mathrm{m}^{2}\right)$ & $11.23-38.41$ & $15.08(3.28)[15.52-16.12]$ \\
Height percentile & $<0-98$ & $22.00(41)[27.95-33.52]$ \\
Weight percentile & $<0-99$ & $13.00(34)[20.66-25.94]$ \\
BMl percentile & $<0-99$ & $19.00(44)[25.11-30.79]$ \\
Height z-score & $-5.18-2.02$ & $-0.75 \pm 1.11[-0.87--0.64]$ \\
Weight z-score & $-4.73-2.29$ & $-1.12 \pm 1.21[-1.25--0.99]$ \\
BMl z-score & $-6.25-2.19$ & $-0.96 \pm 1.28[-1.09--0.83]$ \\
\hline
\end{tabular}

$B M I$ body mass index, TGA-IgA anti-tissue transglutaminase

${ }^{a}$ Continuous data with normal distribution are expressed as means \pm SDs $[95 \%$ confidence interval] and continuous data with skewed distribution as median (IQR) [95\% confidence interval]

${ }^{\mathrm{b}}$ TGA-IgA levels higher than $100 \mathrm{U} / \mathrm{mL}$ as an indicator of the $\mathrm{CD}$ diagnosis
BMI for age values in the children with CD

Evaluation of BMI based on the criteria of CDC and WHO has been shown in Table 4. According to the percentiles, 93, 252, 10, and 6 patients were considered underweight, normal, overweight, and obese, respectively. Furthermore, the z-scores of BMI were less than 3 in 21 children and more than +2 in only three children. Almost $76 \%$ of the patients had normal BMI for age based on WHO's categorization.

\section{The prevalence of malnutrition in the children with $C D$}

The prevalence of malnutrition, including stunting (low height for age), underweight (low weight for age), overweight, and obesity, among the children was evaluated according to WHO's definitions. However, wasting could not be assessed due to its definition (low weight for height in less than 10-year-old children) and the participants' wide age variation [24]. Based on the results, 10, $22.4,3.9$, and $0.8 \%$ of the patients suffered from stunting, underweight, overweight, and obesity, respectively.

\section{The effect of the disease duration on height, weight, and BMI}

We considered the time span between the age of diagnosis of celiac disease by gastroenterologist and the first visit to specialized nutrition and diet therapy clinic as disease duration. Our aim was to assess the effect of the disease duration on height, weight, and BMI. The results revealed no significant difference among the participants with short, normal, and tall statures concerning the duration of the disease ( $p=0.97$ for CDC and $p=0.98$ for WHO). The results also indicated no significant difference among the underweight, normal, and overweight individuals with respect to the duration of the disease $(p=0.61$ for CDC and $p=0.64$ for WHO). There was also no significant difference with regard to BMI according to the criteria of CDC $(p=0.95)$ and WHO $(p=0.48)$ (Table 5).

\section{Clinical manifestations in the children with $C D$}

Common symptoms of $\mathrm{CD}$ among the children have been summarized in Table 6. Accordingly, the most common problems among the patients were abdominal pain (56.5\%), skeletal pain (28\%), constipation (27.4\%), and anemia (23.8\%). Furthermore, $16.3 \%$ of the participants had the experience of weight loss. Other GI manifestations, such as diarrhea (15\%), flatulence (15\%), lactose intolerance (10.8\%), and nausea (3.6\%), were also present.

\section{Discussion}

The present cross-sectional study provided information about weight, height, BMI, malnutrition prevalence, and clinical features related to $\mathrm{CD}$ in pediatrics. Considering malnutrition status, most of the children with celiac 
Table 2 The frequency distribution of height for age in the children with celiac disease according to the criteria of CDC and WHO

\begin{tabular}{lllll}
\hline Height for age & \multicolumn{2}{l}{ CDC's criteria (percentile) N (\%) } & WHO's criteria (z-score) N (\%) \\
\hline Short stature & $<5$ & $66(18.3)$ & $<-2$ & $36(10)$ \\
Normal stature & $5-95$ & $290(80.3)$ & $-2++2$ & $324(89.7)$ \\
Tall stature & $\geq 95$ & $5(1.4)$ & $\geq+2$ & $1(0.3)$ \\
\hline
\end{tabular}

$C D C$ center for disease control and prevention, $W H O$ world health organization

disease were in the normal range and a small proportion of them were malnourished. Based on the CDC's criteria, $18.3,28.8$, and $25.8 \%$ of the participants had short stature, low body weight, and low BMI for age, respectively. In addition, according to the WHO's categorization, $10 \%$ of the patients had short stature for age and $22.4 \%$ had low body weight for age, while almost $5.8 \%$ were severely thin based on BMI for age. However, few people were overweight and obese, which was unpredictable in people with $\mathrm{CD}$. Furthermore, abdominal pain, skeletal pain, constipation, and anemia were the most common clinical symptoms amongst the children with $\mathrm{CD}$.

In the last few decades, the clinical features of $\mathrm{CD}$ have changed remarkably. The classic picture of $C D$ is shrinking, while asymptomatic or with few symptoms forms of CD have become dominant [25]. Nowadays, growth failure and short stature have been reported as the most common extra-intestinal features of $C D$, originating from the malabsorption syndrome $[17,26]$. Although the exact mechanism of short stature is not obvious, nutrient deficiency, resistance to $\mathrm{GH}$, and low level of IGF-1 have been proposed for growth retardation in children suffering from $C D$ [27]. In some children, the only manifestation of $\mathrm{CD}$ is impaired growth, which makes the disease diagnosis difficult [28]. Moreover, there is an evidence that CD can affect children's stature and cause growth retardation beyond $\mathrm{GH}$ deficiency [17]. According to the results of the present research, 18.3 and $10 \%$ of the children had short stature based on the criteria of $\mathrm{CDC}$ and $\mathrm{WHO}$, respectively. Similar results were also obtained in some other studies. For instance, Giovenale et al. evaluated 7066 children with short stature at the age of 2-14 years and came to the conclusion that 44 children (0.63\%) had CD [29]. In addition, Assiri performed a study on children in Saudi Arabia and indicated that $10.9 \%$ of those with short stature had $\mathrm{CD}$, while $4.3 \%$ of them were suspicious to have CD [18]. In the same line, Jaweria Masood et al. assessed
300 children with short stature and demonstrated that 120 ones suffered from CD [30]. Farooq et al. also disclosed that $12 \%$ of the children with atypical CD had short stature and 30\% had anemia together with short stature [31].

The results of the current study showed that approximately $20-30 \%$ of the children with CD were malnourished in terms of low body weight and low BMI for age. Intestinal mucosal damage in $\mathrm{CD}$ leads to non-optimal weight gain and malnutrition due to malabsorption of such nutrients as glucose, fatty acids, calcium, iron, vitamins, and electrolytes [32, 33]. In addition, due to impaired nutrients absorption in patients with $\mathrm{CD}$, carbohydrates oxidize more to provide energy [33]. Bardella et al. maintained that weight, BMI, lean mass, and fat mass were significantly lower in patients with $C D$ compared to the controls [34]. Furthermore, Barera et al. indicated that the patients with untreated $C D$ had lower fat mass and body weight compared to their matched participants in the control group [35]. Moreover, Dehbozorgi et al. indicated that 31 and $29 \%$ of the children with $\mathrm{CD}$ suffered from low body weight and low BMI for age, respectively [4]. In the present study also, approximately $1-5 \%$ of the patients were overweight and obese based on both WHO and CDC's criteria. Although it has been assumed that patients with $\mathrm{CD}$ are likely to be underweight, some evidence has suggested that these patients were increasingly overweight or obese at the time of diagnosis $(8-40 \%)$ in western countries, and that $\mathrm{CD}$ could coexist with obesity in both children and adults [29-31]. The results of the study by Calcaterra demonstrated that among 200 overweight and obese children, $4 \%$ of them suffered from CD [36]. Nenna et al. also reported that among 1527 overweight/obese children and adolescents, $11.1 \%$ were positive for celiac disease [37]. Another study in Saudi pediatric population showed that in 119 cases diagnosed with $\mathrm{CD}, 48 \%$ had normal growth or were overweight/

Table 3 The frequency distribution of weight for age in the children with celiac disease according to the criteria of CDC and WHO

\begin{tabular}{lllll}
\hline Weight for age & \multicolumn{2}{l}{ CDC's criteria (percentile) N (\%) } & WHO's criteria (z-score) N (\%) \\
\hline Underweight & $<5 \%$ & $104(28.8)$ & $<-2$ & $81(22.4)$ \\
Normal weight & $5-95 \%$ & $252(69.8)$ & $-2-{ }_{-2}$ & $276(76.5)$ \\
Overweight & $\geq 95 \%$ & $5(1.4)$ & $\geq+2$ & $4(1.1)$ \\
\hline
\end{tabular}

$\overline{C D C}$ centers for disease control and prevention, $W H O$ world health organization 
Table 4 The frequency distribution of BMI for age in the children with celiac disease according to the criteria of CDC and WHO

\begin{tabular}{|c|c|c|c|c|c|}
\hline \multicolumn{3}{|c|}{ CDC's criteria (percentile) N (\%) } & \multicolumn{3}{|c|}{ WHO's criteria (z-score) N (\%) } \\
\hline- & & & Severe thinness & $<-3$ & $21(5.8)$ \\
\hline Underweight & $<5$ & $93(25.8)$ & Thinness & $-3--2$ & $50(13.9)$ \\
\hline Normal & 5 & $252(69.8)$ & Normal & $-2-1$ & $273(75.6)$ \\
\hline Overweight & 85 _ 95 & $10(2.8)$ & Overweight & $1-2$ & $14(3.9)$ \\
\hline Obese & $\geq 95$ & $6(1.7)$ & Obese & $\geq 2$ & $3(0.8)$ \\
\hline
\end{tabular}

$C D C$ center for disease control and prevention, $W H O$ world health organization

obese [38]. Singh et al. indicated in their study that 21 out of the 210 cases $(9.1 \%)$ were overweight and obese [39]. Additionally, Valletta et al. showed that 3\% of the children with CD were obese and had z-scores higher than +2 [40]. According to a compensatory hypothesis, nutrients absorption might increase by preserved intestinal cells after a while and lead to excess energy intake [41]. Hence, celiac patients with normal or increased body weight should not be excluded at the diagnosis stage.

In the current study, the most common clinical symptomswere abdominal pain, skeletal pain, constipation, and anemia. Diabetes and hypothyroidism were also prevalent as comorbidities in these patients. The previous reports focused on GI symptoms, especially diarrhea, in CD. The present study findings indicated that $15 \%$ of the patients had diarrhea as a comorbidity. However, atypical CD that presents with extra-intestinal features in the absence of diarrhea is now predominant [42]. A study by EhsaniArdakan et al. indicated that the majority of the patients with CD (range: 1-87 years) had diarrhea, dyspepsia, and constipation. Based on non-GI presentation, however, anemia and osteopenia were the most prevalent symptoms [43]. Reilly et al. also stated that growth problems, abdominal pain, autoimmune thyroid disease, and T1DM were prevalent in the children with CD [44]. Based on the results of a recent meta-analysis, the worldwide prevalence of $\mathrm{CD}$ varied from 0.7 to $1.4 \%$ [45], and T1DM was associated with a high risk of $\mathrm{CD}$ and increased the risk of $\mathrm{CD}$ by up to 20 folds [46]. Some studies have claimed that early exposure to gluten might increase the risk of both CD and T1DM [47-49]. Additionally, Sategna-Guidetti et al. evaluated 241 untreated adults with CD and showed the three-fold higher prevalence of thyroid disease among the patients. Besides, $12.9 \%$ of the patients were diagnosed with hypothyroidism [50]. As the subclinical type of CD in the context of autoimmune diseases has become more prevalent [51], early and proper evaluation of these patients is of paramount importance.

TGA-IgAand duration of CD are two probable factors related to the disease severity. Different studies on pediatrics have shown TGA-IgA level as a predictor of villous atrophy $[52,53]$ and TGA-IgA levels higher than $100 \mathrm{U} / \mathrm{mL}$ as an indicator of the CD diagnosis [54]. In this context, Singh et al. found that increased mucosal abnormality was accompanied by an increase in the TGA-IgA level [55]. In addition celiac manifestations could be parallel with organ-specific autoimmunity in long term and age at diagnosis is the only remarkable predictor of developing an additional autoimmune disease [56]. Duration of exposure to gluten has also been reported to play a critical role in development of CD. Ventura et al. demonstrated that gluten exposure increased the risk of other autoimmune complications in $\mathrm{CD}$ [57]. Also evidence has shown that various indices

Table 5 Comparison of disease duration regarding height, weight, and BMl based on the criteria of CDC and WHO

\begin{tabular}{|c|c|c|c|c|c|c|}
\hline \multicolumn{2}{|c|}{ Variables based on the CDC's criteria } & \multirow{2}{*}{$\begin{array}{l}\text { Duration (years) } \\
\text { Mean } \pm \text { SD } \\
1.34 \pm 2.25\end{array}$} & \multirow{2}{*}{$\begin{array}{c}P \text {-value } \\
0.97\end{array}$} & \multirow{2}{*}{$\begin{array}{l}\text { Variables based on } \\
\text { the WHO's criteria } \\
\text { Short }\end{array}$} & \multirow{2}{*}{$\begin{array}{l}\text { Duration (years) } \\
\text { Mean } \pm \text { SD } \\
1.60 \pm 2.69\end{array}$} & \multirow{2}{*}{$\frac{P \text {-value }}{0.98}$} \\
\hline Height & Short & & & & & \\
\hline & Normal & $1.36 \pm 2.13$ & & Normal & $1.32 \pm 2.07$ & \\
\hline & Tall & $0.83 \pm 1.32$ & & Tall & $0.00 \pm 0.00$ & \\
\hline \multirow[t]{3}{*}{ Weight } & Underweight & $1.41 \pm 2.22$ & 0.61 & Underweight & $1.40 \pm 2.27$ & 0.64 \\
\hline & Normal & $1.33 \pm 2.12$ & & Normal & $1.33 \pm 2.11$ & \\
\hline & Overweight & $1.15 \pm 1.68$ & & Overweight & $1.43 \pm 1.79$ & \\
\hline \multirow[t]{4}{*}{ BMI } & Underweight & $1.13 \pm 1.74$ & 0.95 & Severe thinness & $1.37 \pm 2.17$ & 0.48 \\
\hline & Normal & $1.44 \pm 2.31$ & & Thinness & $1.03 \pm 1.75$ & \\
\hline & Overweight & $1.12 \pm 1.31$ & & Normal & $1.41 \pm 2.25$ & \\
\hline & Obese & $1.16 \pm 1.50$ & & Overweight and obese & $1.18 \pm 1.31$ & \\
\hline
\end{tabular}


Table 6 The frequency distribution of the clinical symptoms observed in the children with celiac disease

\begin{tabular}{llll}
\hline Clinical symptoms & $\mathbf{N}(\%)$ & Clinical symptoms & $\mathbf{N}(\%)$ \\
\hline Diarrhea & $54(15)$ & Skin dryness & $54(15)$ \\
Flatulence & $54(15)$ & Weight Loss & $59(16.3)$ \\
Abdominal pain & $204(56.5)$ & Nausea & $13(3.6)$ \\
Abdominal distention & $5(1.4)$ & Hair loss & $35(9.7)$ \\
Constipation & $99(27.4)$ & Anemia & $86(23.8)$ \\
Skeletal pain & $101(28)$ & Lactose intolerance & $39(10.8)$ \\
\hline
\end{tabular}

including disease duration, the number of diabetes autoantibodies, and the adherence to GFD seems to affect the trend of CD related autoimmune response after GFD regimen [58]. However, the present study results revealed no significant relationships between the disease duration and anthropometric indices. In the same vein, Seyhan et al. indicated no significant relationships between the cutaneous results and the disease duration. However, mucosal findings were more severe in the patients with longer $\mathrm{CD}$ durations [59].

Limitations: One of the strong points of the present investigation was the expression of anthropometric data based on both CDC and WHO's criteria. However, the main limitation of this research was the lack of data about the patients' dietary intakes, which impeded the investigation of the relationship between anthropometric indices and dietary factors. Another study limitation was the lack of information about the serum levels of growth hormone and insulin. If body composition and Bone Mineral Density (BMD) were assessed by Dual-Energy X-ray Absorptiometry (DEXA) method and serum levels of nutritional indices like serum albumin, prealbumin, vitamin D, calcium, phosphorus, and iron were assessed, the interpretation of malnutrition and evaluation of growth failure would be easier. Another limitation of this study was the lack of a control group. Finally, since the study was conducted on a wide age category, weight for height as a good index for assessing malnutrition could not be evaluated.

\section{Conclusion}

This study clearly showed that CD could affect the growth rate of the children in terms of height and weight. Although the common presentation of classic CD in pediatrics is growth retardation, some cases of overweight and obesity were detected in this population. In addition to GI symptoms, including abdominal pain and constipation, such extra-intestinal features as skeletal pain and anemia were prevalent, as well. Considering the ascending trend of $\mathrm{CD}$ incidence, appropriate nutritional evaluation of these patients is essential in early ages for proper diagnosis and management. Moreover, future studies are required to apply solutions to reduce CD-related complications.

\section{Abbreviations}

CD: Celiac disease; BMI: Body mass index; CDC: Center for disease control and prevention; WHO: World health organization; GI: Gastrointestinal; IBS: Irritable bowel syndrome; IGF-1: Insulin growth factor-1; GH: Growth hormone; TGA-IgA: Anti-tissue transglutaminase; SD: Standard deviation; T1DM: Type 1 diabetes mellitus; BMD: Bone mineral density; DEXA: Dualenergy X-ray absorptiometry

\section{Acknowledgments}

The authors would like to appreciate Miss S. Saboori at the Research Consultation Center (RCC) of Shiraz University of Medical Sciences for statistical consulting. They are also grateful for Ms. A. Keivanshekouh at the Research Improvement Center of Shiraz University of Medical Sciences for improving the use of English in the manuscript.

\section{Authors' contributions}

ZS: design, data gathering, data analysis, and preparing the manuscript. $\mathrm{NH}$ : data gathering and preparing the manuscript. ME: concept, design, data analysis, and preparing the manuscript. All authors have read and approved the manuscript.

\section{Funding}

This manuscript was extracted from an MSc thesis written by Zahra Setavand and financially supported by Shiraz University of Medical Sciences.

Availability of data and materials

The datasets used and/or analyzed during the current study is available from the corresponding author upon request.

\section{Declarations}

Ethics approval and consent to participate

This study was approved by the Ethics Committee of Shiraz University of Medical Sciences (IR.SUMS.REC.1398.1153). All methods in the present study were performed in accordance with the principles of the relevant guidelines and regulations of Declaration of Helsinki, which is a statement of ethical principles that directs physicians and other participants in medical research involving human subjects. Informed consent was also obtained from the parents/legal guardians of the patients involved in the study after explaining the aim, method, and goal of the research.

Consent for publication

Not applicable.

\section{Competing interests}

The authors declare that they have no competing interests.

\section{Author details}

${ }^{1}$ Student Research Committee, Shiraz University of Medical Sciences, Shiraz, Iran. ${ }^{2}$ Nutrition Research Center, Department of Clinical Nutrition, School of Nutrition and Food Sciences, Shiraz University of Medical Sciences, Shiraz, Iran. ${ }^{3}$ Neonatal Research Center, Shiraz University of Medical Sciences, Shiraz, Iran.

Received: 9 January 2021 Accepted: 22 March 2021

Published online: 29 March 2021

\section{References}

1. Mearin ML. Celiac disease among children and adolescents. Curr Problems Pediatr Adolesc Health Care. 2007;37(3):86-105. https://doi.org/10.1016/j. cppeds.2007.01.001.

2. Fasano A, Catassi C. Celiac disease. N Engl J Med. 2012;367(25):2419-26. https://doi.org/10.1056/NEJMcp1113994.

3. Green PH, Cellier C. Celiac disease. N Engl J Med. 2007;357(17):1731-43. https://doi.org/10.1056/NEJMra071600.

4. Dehbozorgi M, Honar N, Ekramzadeh M, Saki F. Clinical manifestations and associated disorders in children with celiac disease in southern Iran. BMC Pediatr. 2020;20(1):1-7.

5. Dehghani SM, Haghighat M, Mobayen A, Rezaianzadeh A, Geramizadeh B. Prevalence of celiac disease in healthy Iranian school children. Ann Saudi Med. 2013;33(2):159-61. https://doi.org/10.5144/0256-4947.2013.159. 
6. Nejad MR, Rostami K, Emami MH, Zali MR, Malekzadeh R. Epidemiology of celiac disease in Iran: a review. Middle East J Dig Dis. 2011;3(1):5.

7. Halfdanarson TR, Litzow MR, Murray JA. Hematologic manifestations of celiac disease. Blood. 2007;109(2):412-21. https://doi.org/10.1182/blood-2 006-07-031104.

8. Akman S, Şahaloğlu Ö, Dalkan C, Bahçeciler NN, Arıkan Ç. Is celiac disease misdiagnosed in children with functional constipation? Turk J Gastroenterol. 2018;29(2):210-4. https://doi.org/10.5152/tjg.2018.17369.

9. Jabari M. Use of Growth Hormone Therapy in Patients with Celiac Disease, An Overview. Life Sci J. 2016;13(9):41-7.

10. Caio G, Volta U, Sapone A, Leffler DA, De Giorgio R, Catassi C, et al. Celiac disease: a comprehensive current review. BMC Med. 2019;17(1):1-20.

11. Ludvigsson JF, Leffler DA, Bai JC, Biagi F, Fasano A, Green PH, et al. The Oslo definitions for coeliac disease and related terms. Gut. 2013;62(1):43-52. https://doi.org/10.1136/gutjnl-2011-301346.

12. Oliveira GN, Mohan R, Fagbemi A. Review of celiac disease presentation in a pediatric tertiary Centre. Arq Gastroenterol. 2018;55(1):86-93. https://doi. org/10.1590/s0004-2803.201800000-17.

13. Barker JM, Liu E. Celiac disease: pathophysiology, clinical manifestations, and associated autoimmune conditions. Adv Pediatr. 2008;55(1):349-65. https:// doi.org/10.1016/j.yapd.2008.07.001.

14. Capristo E, Addolorato G, Mingrone G, De Gaetano A, Greco AV, Tataranni PA, et al. Changes in body composition, substrate oxidation, and resting metabolic rate in adult celiac disease patients after a 1-y gluten-free diet treatment. Am J Clin Nutr. 2000;72(1):76-81. https://doi. org/10.1093/ajcn/72.1.76.

15. Meazza C, Pagani S, Gertosio C, Bozzola E, Bozzola M. Celiac disease and short stature in children. Expert Rev Endocrinol Metab. 2014;9(5):535-42. https://doi.org/10.1586/17446651.2014.932248.

16. Yuan J, Gao J, Li X, Liu F, Wijmenga C, Chen H, et al. The tip of the "celiac iceberg" in China: a systematic review and meta-analysis. Plos One. 2013; 8(12):e81151. https://doi.org/10.1371/journal.pone.0081151.

17. Catassi C, Fasano A. Celiac disease as a cause of growth retardation in childhood. Curr Opin Pediatr. 2004;16(4):445-9. https://doi.org/10.1097/01. mop.0000133637.64414.20.

18. Assiri AMA. Isolated short stature as a presentation of celiac disease in Saudi children. Pediatr Rep. 2010;2(1):e415-7.

19. Ludvigsson JF, Rubio-Tapia A, Van Dyke CT, Melton LJ III, Zinsmeister AR, Lahr BD, et al. Increasing incidence of celiac disease in a north American population. Am J Gastroenterol. 2013;108(5):818-24. https://doi.org/10.103 8/ajg.2013.60.

20. Lee R. Biochemical assessment of nutritional status. Lee RD, Nieman DC, eds. Nutritional Assessment: Ney York. McGraw-Hill. Appalachian State University; 2013

21. Dehghani SM, Ostovar S, Ataollahi M, Javaherizadeh $\mathrm{H}$. The effect of glutenfree diet among celiac patients aged 3-12 years old on BMl during 2006 to 2014 at Nemazee teaching hospital. Rev Gastroenterol Peru. 2018;37(4):323-8.

22. Clinical Growth Charts. Available from: https://www.cdc.gov/growthcharts/ clinical_charts.htm. Accessed 8 Nov 2020

23. The WHO Child growth standards. Available from: https://www.who.int/ childgrowth/standards/en/. Accessed 17 Nov 2020

24. Malnutrition. Available from: https://www.who.int/news-room/fact-sheets/ detail/malnutrition. Accessed 20 Nov 2020

25. Hashemi J, Hajiani E, Shahbazin H, Masjedizadeh R, Ghasemi N. Prevalence of celiac disease in Iranian children with idiopathic short stature. World J Gastroenterol. 2008;14(48):7376. https://doi.org/10.3748/wjg.14.7376.

26. Cornean RE, Gheban D, Simionescu B, Margescu M. Celiac disease among adolescents. Poor growth and delayed puberty. Int J Celiac Dis. 2018;2:52-7.

27. Nemet D, Raz A, Zifman E, Morag H, Eliakim A. Short stature, celiac disease and growth hormone deficiency. J Pediatr Endocrinol Metab. 2009;22(10): 979-84.

28. Tümer L, Hasanoglu A, Aybay C. Endomysium antibodies in the diagnosis of celiac disease in short-statured children with no gastrointestinal symptoms. Pediatr Int. 2001;43(1):71-3. https://doi.org/10.1046/j.1442-200x.2001.01327.x.

29. Giovenale D, Meazza C, Cardinale GM, Sposito M, Mastrangelo C, Messini B, et al. The prevalence of growth hormone deficiency and celiac disease in short children. Clin Med Res. 2006;4(3):180-3. https://doi.org/10.3121/ cmr.4.3.180.

30. Masood J, Rehman H, Anjum ZM, lqbal I, Zafar S, Ayesha H. Prevalence of celiac disease in idiopathic short stature children presenting in OPD of children hospital, Faisalabad. Ann Punjab Med Coll. 2020;14(1):9-12.
31. Farooq A, Sheikh TK, Bashir H, Haroon S. Celiac Disease in children and the impact of late diagnosis. Methodology. 2020;12(3):136-40.

32. Parada AC, Mendez C, Aguirre C. Excess weight and gastrointestinal symptoms in Chilean celiac patients at the time of diagnosis. Rev Esp Enferm Dig. 2019;111(5):384-8.

33. Costa A, Brito GA. Anthropometric parameters in celiac disease: a review on the different evaluation methods and disease effects. J Nutr Metab. 2019; 2019:1-9. https://doi.org/10.1155/2019/4586963.

34. Bardella MT, Fredella C, Prampolini L, Molteni N, Giunta AM, Bianchi PA. Body composition and dietary intakes in adult celiac disease patients consuming a strict gluten-free diet. Am J Clin Nutr. 2000;72(4):937-9. https://doi.org/10.1093/ajcn/72.4.937.

35. Barera G, Mora S, Brambilla P, Ricotti A, Menni L, Beccio S, et al. Body composition in children with celiac disease and the effects of a gluten-free diet: a prospective case-control study. Am J Clin Nutr. 2000;72(1):71-5. https://doi.org/10.1093/ajcn/72.1.71

36. Calcaterra V, Regalbuto C, Manuelli M, Klersy C, Pelizzo G, Albertini R, et al, Screening for celiac disease among children with overweight and obesity: toward exploring celiac iceberg. J Pediatr Endocrinol Metab. 2020;33(8):9951002.

37. Nenna R, Mosca A, Mennini M, Papa RE, Petrarca L, Mercurio R, et al. Coeliac disease screening among a large cohort of overweight/obese children. J Pediatr Gastroenterol Nutr. 2015;60(3):405-7. https://doi.org/10.1097/MPG. 0000000000000656

38. Al-Hussaini A, Troncone R, Khormi M, AlTuraiki M, Alkhamis W, Alrajhi M, et al. Mass screening for celiac disease among school-aged children: toward exploring celiac iceberg in Saudi Arabia. J Pediatr Gastroenterol Nutr. 2017; 65(6):646-51. https://doi.org/10.1097/MPG.0000000000001681.

39. Singh I, Agnihotri A, Sharma A, Verma AK, Das P, Thakur B, et al. Patients with celiac disease may have normal weight or may even be overweight. Indian J Gastroenterol. 2016;35(1):20-4. https://doi.org/10.1007/s12664-0160620-9.

40. Valletta E, Fornaro M, Cipolli M, Conte S, Bissolo F, Danchielli C. Celiac disease and obesity: need for nutritional follow-up after diagnosis. Eur J Clin Nutr. 2010;64(11):1371-2. https://doi.org/10.1038/ejcn.2010.161.

41. Diamanti A, Capriati T, Basso MS, Panetta F, Di Ciommo Laurora VM, Bellucci F, et al. Celiac disease and overweight in children: an update. Nutrients. 2014;6(1):207-20. https://doi.org/10.3390/nu6010207.

42. Puri AS, Garg S, Monga R, Tyagi P, Saraswat MK. Spectrum of atypical celiac disease in north Indian children. Indian Pediatr. 2004:41(8):822-6.

43. Ehsani-Ardakani MJ, Villanacci V, Volta U, Manenti S, Caio G, Giovenali P, et al. Gastrointestinal and non-gastrointestinal presentation in patients with celiac disease. Arch Iran Med. 2013;16(2):78.

44. Reilly NR, Aguilar K, Hassid BG, Cheng J, DeFelice AR, Kazlow P, et al. Celiac disease in normal-weight and overweight children: clinical features and growth outcomes following a gluten-free diet. J Pediatr Gastroenterol Nutr. 2011;53(5):528-31. https://doi.org/10.1097/MPG.0b013e3182276d5e.

45. Singh P, Arora A, Strand TA, Leffler DA, Catassi C, Green PH, et al. Global prevalence of celiac disease: systematic review and meta-analysis. Clin Gastroenterol Hepatol. 2018;16(6):823-36. e2.

46. Picarelli A, Di Tola M, Sabbatella L, Mercuri V, Pietrobono D, Bassotti G, et al. Type 1 diabetes mellitus and celiac disease: endothelial dysfunction. Acta Diabetol. 2013:50(4):497-503. https://doi.org/10.1007/s00592-011-0301-1.

47. Norris JM, Barriga K, Klingensmith G, Hoffman M, Eisenbarth GS, Erlich HA, et al. Timing of initial cereal exposure in infancy and risk of islet autoimmunity. JAMA. 2003;290(13):1713-20. https://doi.org/10.1001/jama.2 90.13.1713.

48. Ziegler A-G, Schmid S, Huber D, Hummel M, Bonifacio E. Early infant feeding and risk of developing type 1 diabetes-associated autoantibodies. JAMA. 2003;290(13):1721-8. https://doi.org/10.1001/jama.290.13.1721.

49. Norris JM, Barriga K, Hoffenberg EJ, Taki I, Miao D, Haas JE, et al. Risk of celiac disease autoimmunity and timing of gluten introduction in the diet of infants at increased risk of disease. JAMA. 2005;293(19):2343-51. https:// doi.org/10.1001/jama.293.19.2343.

50. Sategna-Guidetti C, Volta U, Ciacci C, Usai P, Carlino A, De Franceschi L, et al. Prevalence of thyroid disorders in untreated adult celiac disease patients and effect of gluten withdrawal: an Italian multicenter study. Am J Gastroenterol. 2001;96(3):751-7. https://doi.org/10.1111/j.15720241.2001.03617.x. 
51. Ch'ng CL, Jones MK, Kingham JG. Celiac disease and autoimmune thyroid disease. Clin Med Res. 2007;5(3):184-92. https://doi.org/10.3121/ cmr.2007.738

52. Dahlbom I, Korponay-Szabó IR, Kovács JB, Szalai Z, Mäki M, Hansson T. Prediction of clinical and mucosal severity of coeliac disease and dermatitis herpetiformis by quantification of IgA/lgG serum antibodies to tissue transglutaminase. J Pediatr Gastroenterol Nutr. 2010;50(2):140-6. https://doi. org/10.1097/MPG.0b013e3181a81384.

53. Alessio MG, Tonutti E, Brusca I, Radice A, Licini L, Sonzogni A, et al. Correlation between IgA tissue transglutaminase antibody ratio and histological finding in celiac disease. J Pediatr Gastroenterol Nutr. 2012;55(1): 44-9. https://doi.org/10.1097/MPG.0b013e3182470249.

54. Mubarak A, Wolters VM, Gmelig-Meyling FH, ten Kate FJ, Houwen RH. Tissue transglutaminase levels above $100 \mathrm{U} / \mathrm{mL}$ and celiac disease: a prospective study. World J Gastroenterol: WJG. 2012;18(32):4399. https://doi.org/10.3748/ wjg.v18.i32.4399

55. Singh P, Kurray L, Agnihotri A, Das P, Verma AK, Sreenivas V, et al. Titers of anti-tissue transglutaminase antibody correlate well with severity of villous abnormalities in celiac disease. J Clin Gastroenterol. 2015;49(3):212-7. https://doi.org/10.1097/MCG.0000000000000105.

56. Tiberti C, Montuori M, Panimolle F, Trovato CM, Anania C, Valitutti F, et al. Screening for type 1 diabetes-, thyroid-, gastric-, and adrenal-specific humoral autoimmunity in 529 children and adolescents with celiac disease at diagnosis identifies as positive one in every nine patients. Diabetes Care. 2017;40(2):e10-e1. https://doi.org/10.2337/dc16-2095.

57. Ventura A, Magazzù G, Greco L. Duration of exposure to gluten and risk for autoimmune disorders in patients with celiac disease. Gastroenterology. 1999;117(2):297-303. https://doi.org/10.1053/gast.1999.0029900297.

58. Tiberti C, Montuori M, Trovato CM, Panimolle F, Filardi T, Valitutti F, et al. Gluten-free diet impact on dynamics of pancreatic islet-specific autoimmunity detected at celiac disease diagnosis. Pediatr Diabetes. 2020 21(5):774-80. https://doi.org/10.1111/pedi.13054

59. Seyhan M, Erdem T, Ertekin V, Selimoğlu MA. The mucocutaneous manifestations associated with celiac disease in childhood and adolescence. Pediatr Dermatol. 2007;24(1):28-33. https://doi.org/10.1111/j.1525-1470.2007. 00328.x.

\section{Publisher's Note}

Springer Nature remains neutral with regard to jurisdictional claims in published maps and institutional affiliations.

Ready to submit your research? Choose BMC and benefit from:

- fast, convenient online submission

- thorough peer review by experienced researchers in your field

- rapid publication on acceptance

- support for research data, including large and complex data types

- gold Open Access which fosters wider collaboration and increased citations

- maximum visibility for your research: over $100 \mathrm{M}$ website views per year

At $\mathrm{BMC}$, research is always in progress.

Learn more biomedcentral.com/submissions 